\title{
Simulation and Optimization of Silicon Solar Cell Back Surface Field
}

\author{
Souad TOBBECHE *, Mohamed Nadjib KATEB \\ Laboratoire des Matériaux Semi-conducteurs et Métalliques, Faculté des Sciences et de la Technologie, Département
de Génie-Electrique, Université de Biskra, B.P 145, Biskra 07000, Algérie
}

cross $^{\text {ref }}$ http://dx.doi.org/10.5755/j01.ms.21.4.9565

Received 23 January 2015; accepted 24 July 2015

\begin{abstract}
In this paper, TCAD Silvaco (Technology Computer Aided Design) software has been used to study the Back Surface Field (BSF) effect of a $\mathrm{p}^{+}$silicon layer for a $\mathrm{n}^{+} \mathrm{pp}^{+}$silicon solar cell. To study this effect, the $J-V$ characteristics and the external quantum efficiency (EQE) are simulated under AM 1.5 illumination for two types of cells. The first solar cell is without BSF ( $\mathrm{n}^{+} \mathrm{p}$ structure) while the second one is with BSF $\left(\mathrm{n}^{+} \mathrm{pp}^{+}\right.$structure). The creation of the BSF on the rear face of the cell results in efficiency $\eta$ of up to $16.06 \%$ with a short-circuit current density $J_{s c}=30.54 \mathrm{~mA} / \mathrm{cm}^{2}$, an open-circuit voltage $V_{o c}=0.631 \mathrm{~V}$, a fill factor $F F=0.832$ and a clear improvement of the spectral response obtained in the long wavelengths range. An electric field and a barrier of potential are created by the BSF and located at the junction $\mathrm{p}^{+} / \mathrm{p}$ with a maximum of $5800 \mathrm{~V} / \mathrm{cm}$ and $0.15 \mathrm{~V}$, respectively. The optimization of the BSF layer shows that the cell performance improves with the $\mathrm{p}^{+}$thickness between $0.35-0.39 \mu \mathrm{m}$, the $\mathrm{p}^{+}$doping dose is about $2 \times 10^{14} \mathrm{~cm}^{-2}$, the maximum efficiency up to $16.19 \%$. The cell efficiency is more sensitive to the value of the back surface recombination velocity above a value of $10^{3} \mathrm{~cm} / \mathrm{s}$ in $\mathrm{n}^{+} \mathrm{p}$ than $\mathrm{n}^{+} \mathrm{pp}^{+}$solar cell.
\end{abstract}

Keywords: simulation, silicon solar cell, BSF, optimization, TCAD Silvaco.

\section{INTRODUCTION}

The efficiency of solar cells is affected by the loss of optically generated minority carriers. One of the major losses is the surface recombination of minority carriers, especially on the back surface, which is opposite to the wafer side of the pn junction. The reduction of the back surface recombination of a solar cell is, however, hindered by various constraints. Since the back of a normal solar cell is completely metal coated, it goes without saying that there is a high-surface recombination velocity (Ohmic metal-semiconductor contacts have high-recombination velocities). One technical measure to improve this situation is the creation of a highly doped $\mathrm{p}^{+}$zone on the back surface of the solar cell base. This $\mathrm{p}^{+} \mathrm{p}$ junction (high-lowjunction) is also known as the back surface field (BSF). Owing to the electric field which is created, less of the minority charge carriers created in the base can recombine on the back surface. The BSF functions like an electrical mirror, throwing back the charge carriers into the inside of the cell. Its behavior depends upon several parameters [1]: the surface concentration of $\mathrm{p}^{+}$doping as well as its concentration profile and penetration depth, recombination in the $\mathrm{p}^{+}$layer itself, and charge carrier density at the junction, i.e. the relationship between diffusion length and crystal thickness.

Crystalline silicon solar cells technology has principally concentrated on reducing the specific consumption of silicon material to enhance the efficiencies of cells and modules and in the longer term on the implementation of new integrated concepts. In the past, many research groups have tried to use very thin bases layers in silicon solar cells, aiming mainly at an overall cost reduction. Important progress made in this field

\footnotetext{
* Corresponding author. Tel/fax: +213 (0) 33543199.

E-mail address: souad_tobbeche@yahoo.fr (S. Tobbeche)
}

between 1990 and 2006 achieved decrease of wafers thickness from 400 to $140 \mu \mathrm{m}$, increase of cell surface from 100 to $240 \mathrm{~cm}^{2}$, as well as increase of modules efficiency from $10 \%$ to already $13 \%$, with the best results above $20 \%$ [2]. The highest efficiency reported to date for a silicon cell is $24.7 \%$ by a method known as PERL (Passivated Emitter, Rear Locally diffused) [3].

Extensive studies on the BSF effect in solar cells have been carried out, which show that the presence of a BSF can lead to a significant improvement in both short-circuit current and open-circuit voltage. Analytical descriptions in which the presence of a BSF was modelled in terms of an effective recombination velocity at the back surface $S_{\text {eff }}$, have been presented by Godlewski et al. [4] and Fossum et al. [5]. In an early study, Fossum [6] explained the device physics of the $\mathrm{n}^{+} \mathrm{pp}^{+}$BSF cell. The increase in the opencircuit voltage was related to the increase in the integrated base doping in conjunction with the degradation of the minority carrier diffusivity in the highly doped region.

Computer aided numerical simulation in one dimension of BSF solar cells, have been presented by Dunbar and Hauser [7, 8], Fossum [9], and Kopp et al. [10]. The results from [10] were calculated with the help of the PC-1D simulator [11] and showed the influence of the BSF layer penetration depth and surface concentration on $V_{o c}$ of $\mathrm{n}^{+} \mathrm{pp}^{+}$silicon solar cell.

Recently, Choe [12] studied the effect of the back surface field in a typical p-type front-lit Si solar cell by use of Medici, a 2-D device simulator. The effect of the BSF layer, in terms of its thickness and doping concentration, on the maximum power output of a front-lit solar cell is simulated. The heavily boron doped $\mathrm{p}^{+}$-type BSF layer is found to improve the solar cell efficiency in general. However, the degree to which the improvement is made depends greatly on the two parameters of the BSF layer: the thickness and the doping concentration. 
In this work, we present a numerical study of the BSF effect on crystalline silicon solar cell performance using TCAD Silvaco software. The basic parameters of the BSF layer, namely the thickness and the doping concentration, and their relation to the photovoltaic parameters and the external quantum efficiency are investigated comprehensively. The most important role of a BSF layer on the reduction of the effect of surface recombination is demonstrated too. TCAD Silvaco software provides capabilities for $2 \mathrm{D}$ and $3 \mathrm{D}$ simulation of semiconductor devices using two-simulation modules Athena (process simulation of structure) [13] and Atlas (electrical characteristics) [14]. We describe the technological process of the $\mathrm{n}^{+} \mathrm{pp}^{+}$structure in Athena and simulation results. Electrical simulation of the solar cell designed in Athena and simulation results in Atlas are presented. To show the effect of BSF in silicon solar cells, we made a comparative study between two cells, the first one with BSF, and the second one without it. The influence of the BSF on the solar cell is examined, and the effects of its thickness and its doping dose are studied and optimized. The effect of the back surface recombination velocity on the efficiency of $\mathrm{n}^{+} \mathrm{p}$ and $\mathrm{n}^{+} \mathrm{pp}^{+}$solar cells is also studied. The role of the $\mathrm{BSF}$ in the improvement of the silicon solar cell performance was simulated and analyzed.

\section{DEVICE STRUCTURE AND INPUT PARAMETERS IN ATHENA}

In Athena, we take a solar cell wafer with (2D) $200 \mu \mathrm{m} \times 200 \mu \mathrm{m}$ in $x$ and $y$. The crystallographic orientation wafer (100) is a p-type silicon (the solar cell base), the impurity concentration of boron is of $2 \times 10^{16} \mathrm{~cm}^{-3}$. The first step consists of the deposition of a silicon nitride anti-reflection and pre-implantation layer $\mathrm{Si}_{3} \mathrm{~N}_{4}$ with a $50 \mathrm{~nm}$ thickness, which also minimizes the number of silicon surface defects. The second operation corresponds to the creation of an active zone $\mathrm{n}^{+}$(the solar cell emitter). It is produced by ion implantation with a phosphorus dose of $10^{16} \mathrm{~cm}^{-2}$ and an energy of $30 \mathrm{keV}$ followed by diffusion. It corresponds to the redistribution of atoms in the wafer and is carried out at a temperature of $850{ }^{\circ} \mathrm{C}$ [15] during $30 \mathrm{~min}$. The net doping profile (the absolute value of the difference between the concentration of acceptors and donors), boron doping and phosphorus doping profiles close to the upper face of the $\mathrm{n}^{+} \mathrm{pp}^{+}$solar cell are plotted in Fig. 1.

A Gaussian profile of the $\mathrm{n}^{+}$region is more visible in this figure. The depth of the junction is in the vicinity of $0.31 \mu \mathrm{m}$ beyond the upper face of the solar cell. The next step is the realization of the $\mathrm{p}^{+}$zone (the solar cell BSF), which is realized by ion implantation of boron $[16,17]$ in silicon with a dose of $2 \times 10^{14} \mathrm{~cm}^{-2}$ and an energy of $70 \mathrm{keV}$ followed by a diffusion phase carried out at a temperature of $1000{ }^{\circ} \mathrm{C}$ [18] during $30 \mathrm{~min}$ to ensure a good redistribution of the atoms in the structure. Fig. 2 represents the net doping profile, boron and phosphorus doping profiles close to the back face of the solar cell. A Gaussian profile of the $\mathrm{p}^{+}$doping appears in this figure, the $\mathrm{p} / \mathrm{p}^{+}$junction depth is of $0.45 \mu \mathrm{m}$ from the rear face of the solar cell. The following operations correspond to the realization of the anode and the cathode.

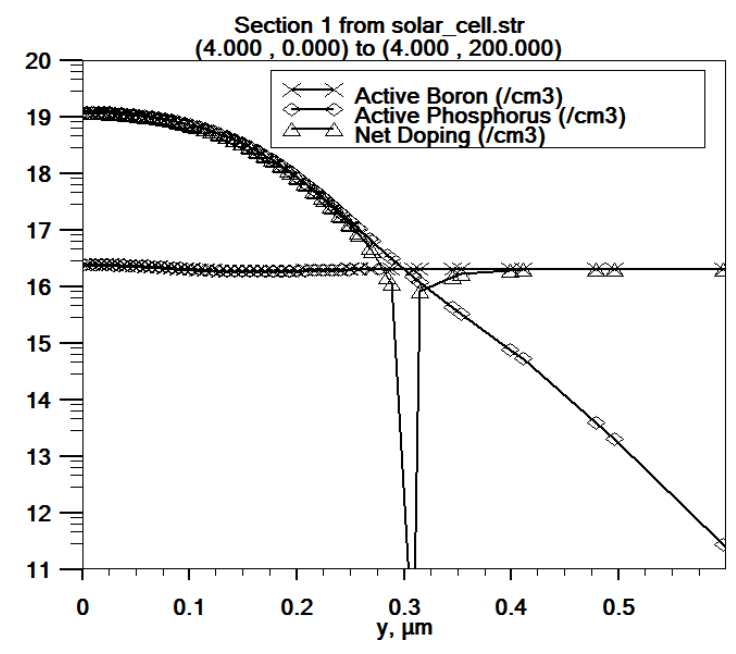

Fig. 1. Net doping profile, boron and phosphorus profiles close to the upper face of the $\mathrm{n}^{+} \mathrm{pp}^{+}$solar cell

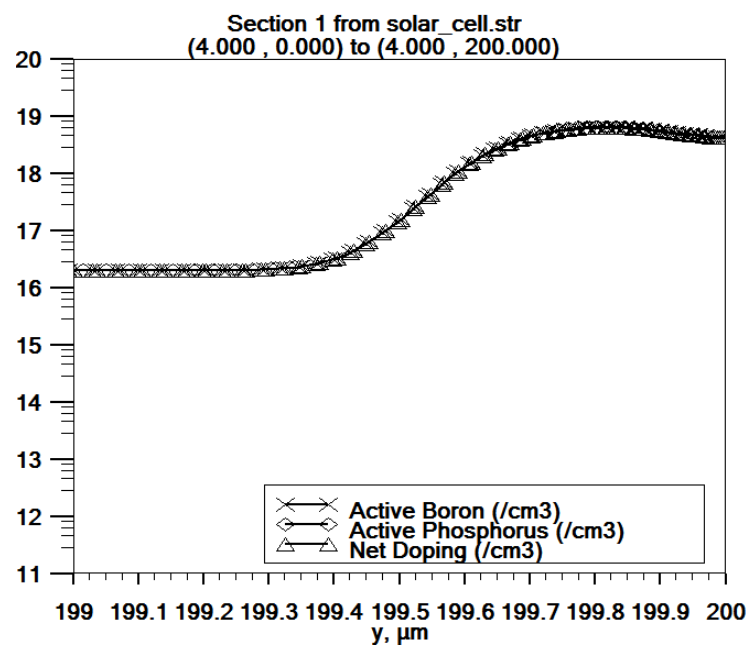

Fig. 2. Net doping profile, boron and phosphorus profiles close to the back face of the $\mathrm{n}^{+} \mathrm{pp}^{+}$solar cell

The cathode contact is made by etching the $\mathrm{Si}_{3} \mathrm{~N}_{4}$ layer and depositing of a $0.1 \mu \mathrm{m}$ thick silver layer, and then an etching operation is necessary to remove the silver on unwanted areas.

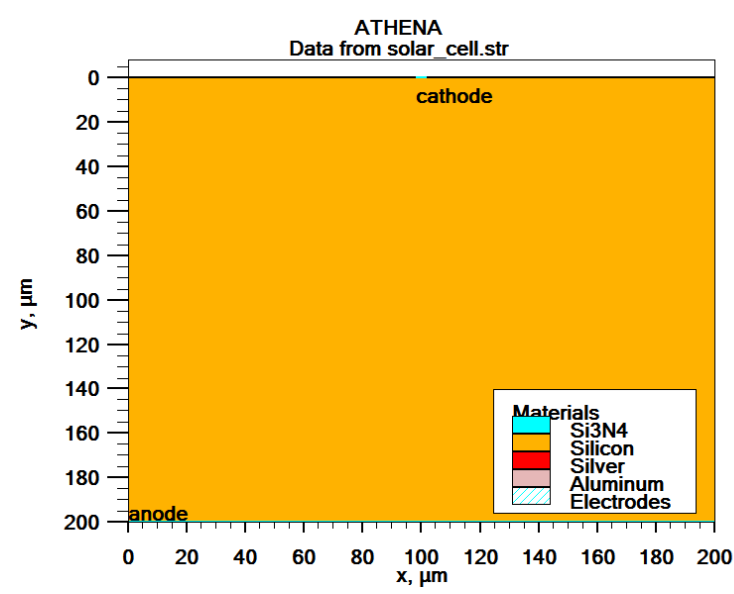

Fig. 3. Whole structure of the $\mathrm{n}^{+} \mathrm{pp}^{+}$solar cell

The silver etching operation fixes the length of the cathode to $2 \mu \mathrm{m}$. The anode contact is executed by depositing a $0.1 \mu \mathrm{m}$ thick aluminum layer over the entire back face of the solar cell.The whole structure of the cell is shown in Fig. 3. 


\section{MODELS AND INPUT PARAMETERS IN ATLAS}

In Atlas, the simulation program must follow a set of ordered instructions which are: Specification of the structure (mesh, regions, electrodes, doping), model specification (materials, models), specification of numerical models (numerical methods for solving equations), solution and results (extraction, curve, plot).

The structure of the solar cell is described in the Athena simulator. Its electrical simulation requires the definition of the material parameters used in its manufacture; such as the band structure, the density of states, affinity, and other parameters used for any simulation. Our solar cell is made of silicon, silver, aluminum and silicon nitride $\mathrm{Si}_{3} \mathrm{~N}_{4}$, these materials are defined by default in Atlas database. The models we used in our simulation are lighted in the documentation of Silvaco Atlas [14] and in the literature, and are summarized as follows: both anode and cathode modeled as Schottky contacts, dependence of the mobility of charge carriers on the doping concentration (CONMOB) and on the electric field (FLDMOB), Shockley-Read-Hall recombination model (SRH) for which the lifetime of the electrons (holes) TAUN0 (TAUP0) $=100 \mu \mathrm{s}$ [19-21], Auger recombination model (AUGER) with their parameters defined by default in Atlas, AUGN $=2.8 \times 10^{-31} \mathrm{~cm}^{6} \mathrm{~s}^{-1}$ and AUGP $=9.9 \times 10^{-32} \mathrm{~cm}^{6} \mathrm{~s}^{-1}$ [14] for silicon, surface recombination model with the upper-surface recombination velocities assumed for electrons (S.N) and for holes (S.P) respectively so that $\mathrm{S} . \mathrm{N}=\mathrm{S} . \mathrm{P}=10^{3} \mathrm{~cm} / \mathrm{s}$ [22], the back surface recombination velocities $\mathrm{S} . \mathrm{N}=\mathrm{S} . \mathrm{P}=10^{6} \mathrm{~cm} / \mathrm{s}$ [23], the effect of the antireflection layer of $\mathrm{Si}_{3} \mathrm{~N}_{4}$ through the interface $\mathrm{Si}_{3} \mathrm{~N}_{4} / \mathrm{Si}$ and the reflectivity effect of the front and back faces of the solar cell. The illumination of the solar cell is by the solar spectrum AM 1.5 with an intensity of $100 \mathrm{~mW} / \mathrm{cm}^{2}$. We used Newton's numerical method for solving semiconductor transport equations formed by a complete set of Poisson and carrier continuity equations [6]. Electrical simulation of the solar cell starts with zero bias on all electrodes (thermal equilibrium state). Once the solution of the thermal equilibrium state is found, it is used to initialize the lightened and polarized state. The solutions obtained are provided either by a graphical interface (TONYPLOT) or by extraction of numerical values (EXTRACT) in Atlas.

\section{RESULTS AND DISCUSSION}

The results of electrical stimulation of $n^{+} p$ and $n^{+} p^{+}$ solar cells are presented knowing that $n^{+} p$ structure is also designed in Athena with the same geometry and the same doping concentrations of both regions $\mathrm{n}^{+}$and $\mathrm{p}$ as those of the $\mathrm{n}^{+} \mathrm{pp}^{+}$structure. Fig. 4 shows the net doping profile, boron doping, and phosphorus doping profiles, the junction depth $\mathrm{n}^{+} / \mathrm{p}$ is in the order of $0.22 \mu \mathrm{m}$ beyond the upper face of the solar cell.

The variation curves of the current density $J$ with the applied voltage $V(J(V))$ and the power density curves $\mathrm{P}$ in terms of the applied voltage $V(P(V))$ delivered by the $\mathrm{n}^{+} \mathrm{p}$ and $\mathrm{n}^{+} \mathrm{pp}^{+}$solar cells under illumination (see Fig. 5).
The photovoltaic parameters of solar cells obtained by simulation such as $V_{o c}, J_{s c}, F F$ and $\eta$, are listed in Table 1.

Table 1. Photovoltaic parameters of $n^{+} p$ and $n^{+} \mathrm{pp}^{+}$solar cells

\begin{tabular}{|c|c|c|c|c|}
\hline Structure & $J_{s c}, \mathrm{~mA} / \mathrm{cm}^{2}$ & $V_{o c}, \mathrm{~V}$ & $F F$ & $\eta, \%$ \\
\hline $\mathrm{n}^{+} \mathrm{p}$ & 28.55 & 0.6 & 0.821 & 14.19 \\
\hline $\mathrm{n}^{+} \mathrm{pp}^{+}$ & 30.54 & 0.631 & 0.832 & 16.06 \\
\hline
\end{tabular}

We notice that the magnitudes of the photovoltaic parameters of the solar cell with BSF $\left(n^{+} p^{+}\right.$structure) are significantly better than those of the solar cell without BSF $\left(\mathrm{n}^{+} \mathrm{p}\right.$ structure). The improvement is especially marked in the short-circuit current density, the open-circuit voltage and the conversion efficiency.

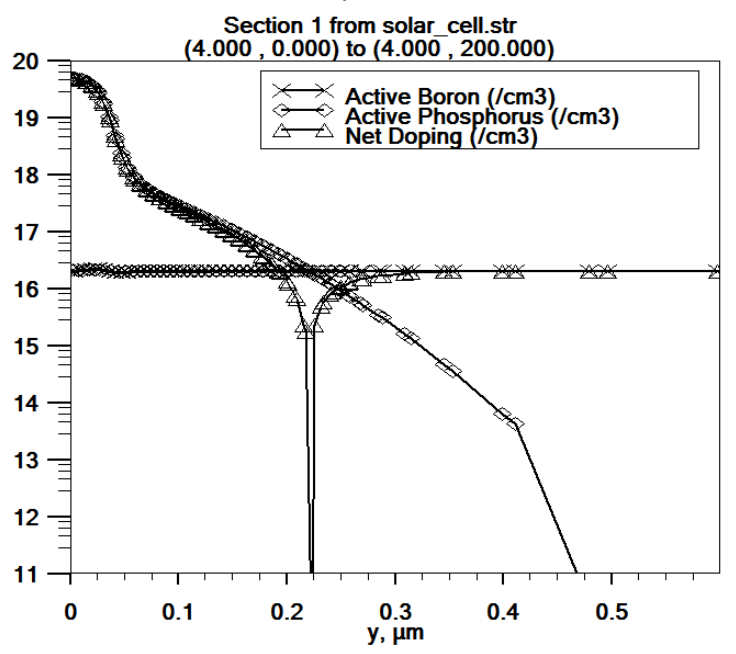

Fig. 4. Net doping profile, boron and phosphorus profiles close to the upper face of the $\mathrm{n}^{+} \mathrm{p}$ solar cell

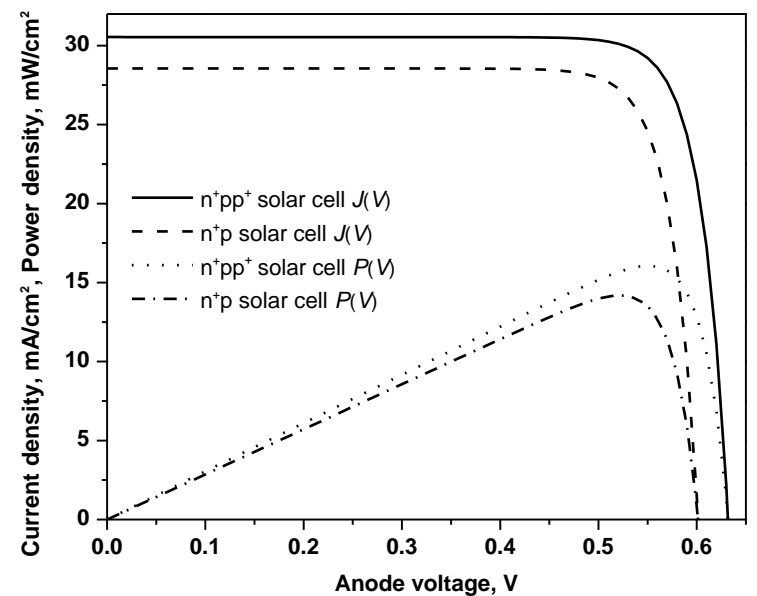

Fig. 5. Current density-voltage characteristics and Power densityvoltage characteristics of the $\mathrm{n}^{+} \mathrm{p}$ and $\mathrm{n}^{+} \mathrm{pp}^{+}$solar cells.

By creating a BSF on the rear face of the cell the shortcircuit current density increases from 28.55 to $30.54 \mathrm{~mA} / \mathrm{cm}^{2}$, the open-circuit voltage from 0.6 to $0.631 \mathrm{~V}$ and the conversion efficiency from 14.19 to $16.06 \%$.

The behaviors of $J_{s c}, V_{o c}$ and $\eta$, are similar to what was observed experimentally in silicon solar cell $[6,8,18]$.

The BSF effect is understandable from the band diagram of the $\mathrm{n}^{+} \mathrm{pp}^{+}$solar cell gained by simulation at thermal equilibrium state (Fig. 6 a).

One notices a barrier of potential $\Psi=0.15 \mathrm{~V}$ induced by the difference in doping values between the $\mathrm{p}$ and $\mathrm{p}^{+}$ 
regions, which tends to confine the electrons (minority carriers) in the base.
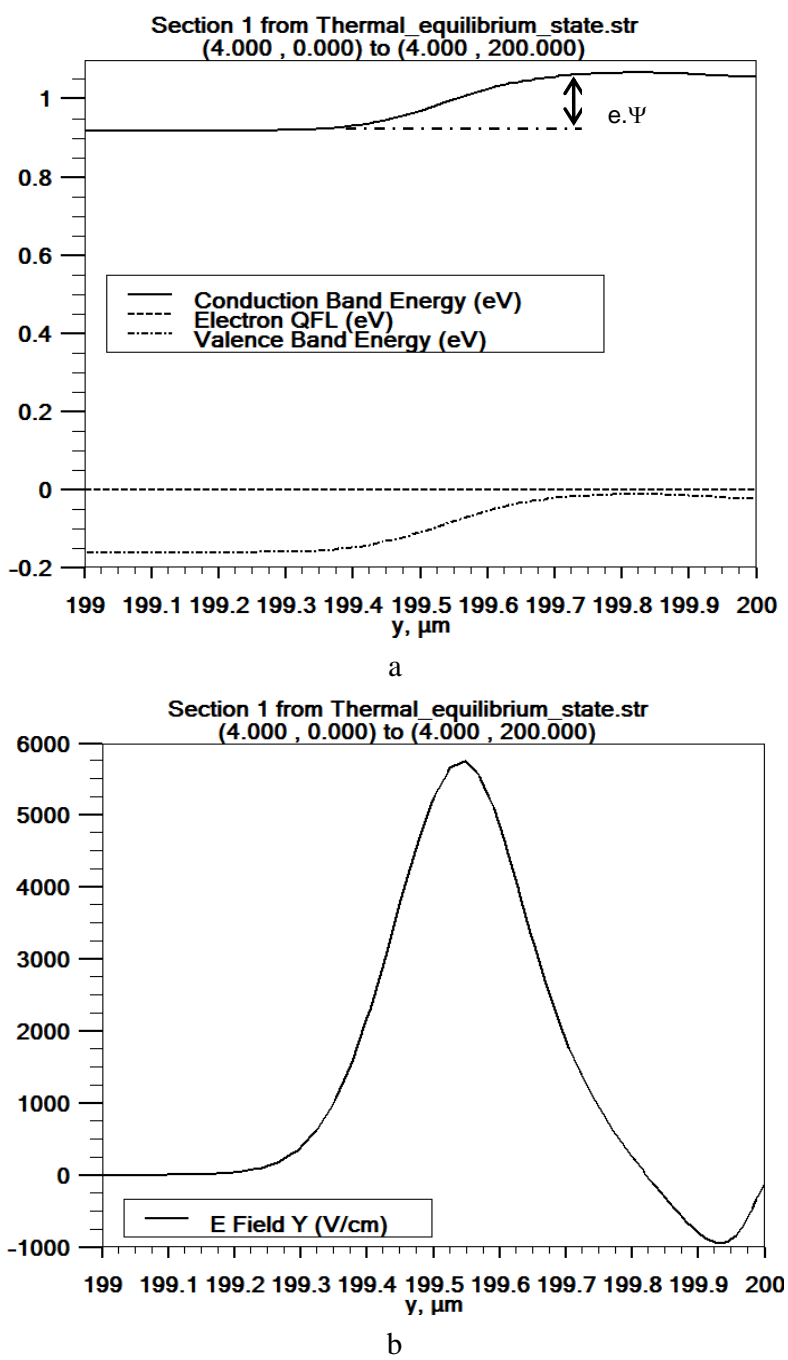

Fig. 6. a - Energy band diagram and Fermi-level versus thickness close to the $\mathrm{n}^{+} \mathrm{pp}^{+}$solar cell back face at the thermal equilibrium state, $\mathrm{b}$-Electric field profile versus thickness close to the $\mathrm{n}^{+} \mathrm{pp}^{+}$solar cell back face at the thermal equilibrium state

They are, therefore kept out of the rear face which is characterized by a very high recombination velocity $\mathrm{S} . \mathrm{N}=10^{6} \mathrm{~cm} / \mathrm{s}$. The electric field on the back face of the cell solar cell is also simulated at thermal equilibrium state (Fig. 6 b). It enables us to observe the creation of an electric field near the back face (BSF).

Its maximum of $5800 \mathrm{~V} / \mathrm{cm}$ is located at the junction $\mathrm{p}^{+} / \mathrm{p}$ at a depth $0.45 \mu \mathrm{m}$ from the back face of the solar cell. The electric field repels diffusing electrons from the $n^{+} / p$ junction back into the $\mathrm{p}$ region and the electrons created, as a result of the long wavelengths of the solar spectrum are moved away from the rear face by this electric field. And, therefore, the recombination of electrons with holes is reduced on the back face which contributes to increasing the cell efficiency [24].

We also used Atlas to simulate the spectral response of both solar cells. The simulation is carried out in shortcircuit case. Fig. 7 represents the external quantum efficiency $E Q E$ with the wavelength. $E Q E$ has the same maximum value close to 0.78 for both solar cells located in an interval of 0.45 and $0.85 \mu \mathrm{m}$ for the $\mathrm{n}^{+} \mathrm{p}$ solar cell, and between 0.45 and $0.95 \mu \mathrm{m}$ for the $\mathrm{n}^{+} \mathrm{pp}^{+}$solar cell; afterwards, it decreases strongly at short and long wavelengths for both solar cells. By comparing the values of $E Q E$ of both structures, we observe that for $\lambda<0.65 \mu \mathrm{m}$, both solar cells have the same spectral response while, for $\lambda \geq 0.65 \mu \mathrm{m}$, the $\mathrm{n}^{+} \mathrm{pp}^{+}$solar cell has a better spectral response than that of the $n^{+} p$ solar cell. The BSF improves significantly the collection of carriers with long wavelengths of the solar spectrum by reducing recombination at the rear face of the $\mathrm{n}^{+} \mathrm{pp}^{+}$solar cell. Therefore, the short-circuit current density increases. The open-circuit voltage is also enhanced due to short-circuit current density increase and the added potential energy $e . \Psi$ between $\mathrm{p}$ and $\mathrm{p}^{+}$regions.

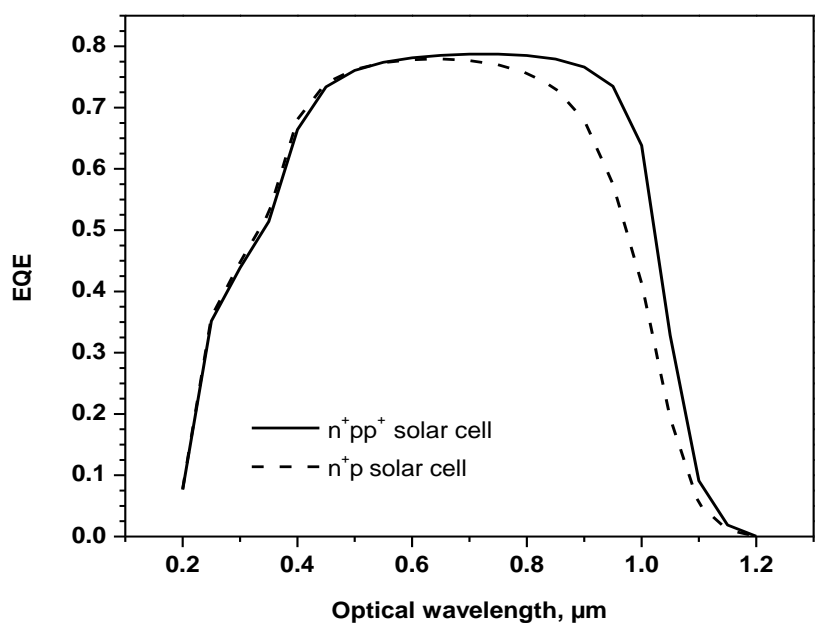

Fig. 7. External quantum efficiency of the $n^{+} p$ and $n^{+} p p^{+}$solar cells at the short-circuit condition.

In order to find out the best parameters of the BSF, we have studied the effects of its thickness and its doping dose on the performance of the solar cell. The variation of the BSF thickness $\left(x_{B S F}\right)$ is carried out in Athena simulator by changing the diffusion time or the diffusion temperature $\left(T_{D}\right)$, in our case we varied $T_{D}$. The photovoltaic parameters of the solar cell obtained by varying $T_{D}\left(x_{B S F}\right)$ are summarized in Table 2.

Table 2. The $\mathrm{n}^{+} \mathrm{pp}^{+}$solar cell photovoltaic parameters as a function of the BSF thickness

\begin{tabular}{|c|c|c|c|c|c|}
\hline $\begin{array}{c}T_{D}, \\
{ }^{\circ} \mathrm{C}\end{array}$ & $\begin{array}{c}x_{B S F}, \\
\mu \mathrm{m}\end{array}$ & $\begin{array}{c}J_{s c}, \\
\mathrm{~mA} / \mathrm{cm}^{2}\end{array}$ & $V_{o c}, \mathrm{~V}$ & $F F$ & $\eta, \%$ \\
\hline 700 & 0.35 & 30.66 & 0.633 & 0.833 & 16.19 \\
\hline 750 & 0.36 & 30.66 & 0.633 & 0.833 & 16.19 \\
\hline 800 & 0.38 & 30.66 & 0.633 & 0.833 & 16.19 \\
\hline 850 & 0.39 & 30.66 & 0.633 & 0.833 & 16.19 \\
\hline 900 & 0.4 & 30.64 & 0.633 & 0.833 & 16.17 \\
\hline 950 & 0.41 & 30.60 & 0.632 & 0.833 & 16.13 \\
\hline 1000 & 0.45 & 30.54 & 0.631 & 0.832 & 16.06 \\
\hline
\end{tabular}

We can see that when the thickness increases the open- circuit voltage and the short-circuit current density are nearly unchanged, and only a slight change in fill factor and cell efficiency. So the efficiency can be considered as independent with the BSF thickness. In the same way, the increase of the BSF thickness improves the external quantum efficiency slightly (see Fig. 8). 


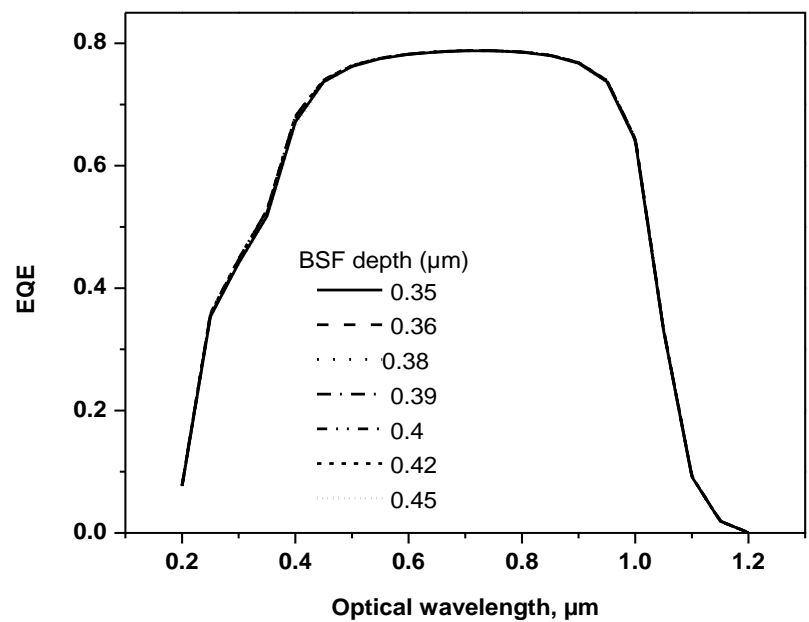

Fig. 8. The external quantum efficiency of the $\mathrm{n}^{+} \mathrm{pp}^{+}$silicon solar cell with the different BSF thickness

It is easy to conclude that the $\mathrm{p}^{+}$silicon layer cannot be too thick. If it is too thick, the carriers cannot arrive at the back contact owing to recombination. The best thickness of the $\mathrm{p}+$ silicon layer is the value of $0.35-0.39 \mu \mathrm{m}$.

Table 3. The $\mathrm{n}^{+} \mathrm{pp}^{+}$solar cell photovoltaic parameters as a function of the BSF doping dose

\begin{tabular}{|c|c|c|c|c|}
\hline Dose, $\mathrm{cm}^{-2}$ & $J_{s c}, \mathrm{~mA} / \mathrm{cm}^{2}$ & $V_{o c}, \mathrm{~V}$ & $F F$ & $\eta, \%$ \\
\hline 2E12 & 28.55 & 0.601 & 0.826 & 14.20 \\
\hline 3E13 & 29.16 & 0.607 & 0.828 & 14.67 \\
\hline 5E13 & 29.56 & 0.612 & 0.829 & 15.01 \\
\hline 8E13 & 29.98 & 0.619 & 0.827 & 15.41 \\
\hline $1.2 \mathrm{E} 14$ & 30.38 & 0.625 & 0.831 & 15.77 \\
\hline 2E14 & 30.66 & 0.633 & 0.833 & 16.19 \\
\hline
\end{tabular}

Table 3 shows the effect of BSF doping dose on the photovoltaic parameters of solar cell, the variation of the BSF doping dose is also carried out in Athena simulator. We notice a clear improvement of the short-circuit current density, the open-circuit voltage and the efficiency with the increase of the doping dose. We also studied the influence of the BSF doping concentration on the external quantum efficiency illustrated in Fig. 9.

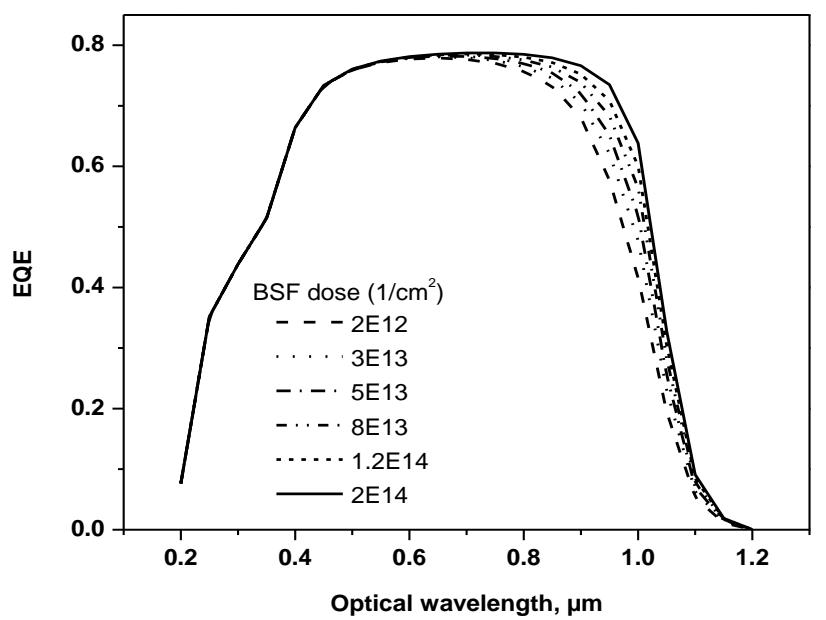

Fig. 9. The external quantum efficiency of the $n^{+} \mathrm{pp}^{+}$silicon solar cell with the different BSF doping dose

An improvement of the external quantum with the increase of the BSF doping dose is also marked. The increase of the $\mathrm{p}^{+}$layer doping enhances the electric field in the $\mathrm{p} / \mathrm{p}^{+}$junction and consequently there is a reduction of the charge carriers recombination in this region, which causes the amplification of the short-circuit current density, the open-circuit voltage, the conversion efficiency and the spectral response. The above analysis indicates the best value of dose of $\mathrm{p}^{+}$silicon layer is $2 \times 10^{14} \mathrm{~cm}^{-2}$ for high-conversion efficiency. The optimization of the BSF layer shows that the cell performance improves with the $\mathrm{p}^{+}$ thickness between $0.35-0.39 \mu \mathrm{m}$, the $\mathrm{p}^{+}$doping dose is about $2 \times 10^{14} \mathrm{~cm}^{-2}$, the maximum efficiency up to $16.19 \%$. The simulated efficiency of $16.19 \%$ is in agreement with the experimental efficiency of $17.12 \%$ measured on $\mathrm{n}^{+} \mathrm{pp}^{+}$silicon solar cell with textured surface [25] knowing that a surface texture enhances the capacity of a solar cell to absorb incident solar radiation and increases its efficiency, thus validating the model and the parameters chosen for the simulation.

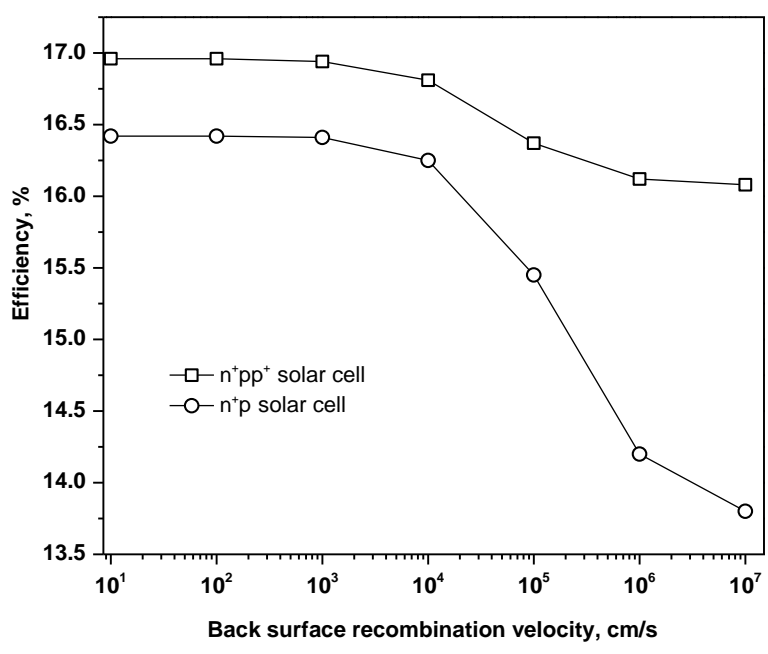

Fig. 10. Variation of efficiency with back surface recombination velocity in $\mathrm{n}^{+} \mathrm{p}$ and $\mathrm{n}^{+} \mathrm{pp}^{+}$solar cells

Fig. 10 shows the efficiency of the studied $n^{+} p$ and $\mathrm{n}^{+} \mathrm{pp}^{+}$solar cells calculated for back surface recombination velocity in the range 10 to $10^{7} \mathrm{~cm} / \mathrm{s}$. As can be seen the surface recombination defects are more deleterious in $n^{+} p$ than $\mathrm{n}^{+} \mathrm{pp}^{+}$solar cell. The efficiency decreases rapidly for a back surface recombination velocity greater than $10^{3} \mathrm{~cm} / \mathrm{s}$ for the $n^{+} \mathrm{p}$ solar cell.It is also observed that the efficiency for a back surface recombination velocity parameter above a value of $10^{3} \mathrm{~cm} / \mathrm{s}$ is less sensitive in the $\mathrm{n}^{+} \mathrm{pp}^{+}$solar cell.

The influence of the back surface recombination in the solar cell with BSF $\left(\mathrm{n}^{+} \mathrm{pp}^{+}\right.$structure) is less significant than in solar cell without it ( $\mathrm{n}^{+} \mathrm{p}$ structure). The back-side builtin electric field opposes the motion of minority carriers (electrons) to the back surface where the surface recombination velocity is high and the efficiency is improved accordingly. The higher simulated efficiency is of $17 \%$ reached for the back surface recombination velocity lower than $10^{3} \mathrm{~cm} / \mathrm{s}$ in BSF solar cell.

\section{CONCLUSION}

The present paper reports on a simulation study carried out to determine and optimize the effect of the $\mathrm{p}^{+} / \mathrm{p}$ junction (high-low-junction) also known as the back surface field (BSF) on silicon solar cell performance. The simulation is effectuated by the TCAD Silvaco software 
using physical device simulation, which not only provides better physics insight but also realistic predictive capability. The photovoltaic parameters of silicon solar cells with back surface field layer $\left(\mathrm{n}^{+} \mathrm{pp}^{+}\right.$structure) and those of the conventional one $\left(\mathrm{n}^{+} \mathrm{p}\right.$ structure) are compared. An improvement of the efficiency is of $16.06 \%\left(\mathrm{n}^{+} \mathrm{pp}^{+}\right.$ structure) compared to $14.19 \%\left(\mathrm{n}^{+} \mathrm{p}\right.$ structure). The results indicate that the most important role played by the back surface field layer is to enhance the collection of light generated free carriers, which improves the efficiency of the long wavelength quantum. The BSF reduced the recombination in the lower part of the solar cell by creating an electric field and a barrier of potential located at the junction $\mathrm{p}^{+} / \mathrm{p}$ with a maximum of $5800 \mathrm{~V} / \mathrm{cm}$ and $0.15 \mathrm{~V}$, respectively. An optimized efficiency is of $16.19 \%$ in agreement with an experimentally determined efficiency [25], a high fill factor of 0.833 and a high $V_{o c}$ of $0.633 \mathrm{~V}$ when the $\mathrm{p}^{+}$thickness is of $0.35-0.39 \mu \mathrm{m}$ and the $\mathrm{p}^{+}$ doping dose is about $2 \times 10^{14} \mathrm{~cm}^{-2}$. The cell efficiency is more sensitive to the value of the back surface recombination velocity above a value of $10^{3} \mathrm{~cm} / \mathrm{s}$ in $\mathrm{n}^{+} \mathrm{p}$ than $\mathrm{n}^{+} \mathrm{pp}^{+}$solar cell. This demonstrates the most important role of a BSF layer on the reduction of the effect of surface recombination.

\section{Acknowledgements}

The authors would like to thank Laboratory of Metallic and Semiconducting Materials (LMSM) of the University of Biskra for providing the Tcad Silvaco software used in the simulation.

\section{REFERENCES}

1. Goetzberger, A., Knobloch, J., Voß, B. Crystalline Silicon Solar Cells. John Wiley \& Sons, England, 1998.

2. Mason, N., Schultz, O., Russel, R., Glunz, S.W., Warta, W. 20.1\% Efficient Large Area Cell on 140 Micron Thin Silicon Wafer Proceedings of the 21st EUPVSE Conference, Dresden, 2006: pp. $521-523$.

3. Green, M.A., $\quad$ Emery, K., King, D.L., Hishikawa, Y., Warta, W. Solar Cell Efficiency Tables (Version 29) Progress in Photovoltaics Research and Applications 15 2007: pp. $35-40$.

http://dx.doi.org/10.1002/pip.741

4. Godlewski, M.P., Baraona, C.R., Brandhorst, H.W. LowHigh Junction Theory Applied to Solar Cells Proceedings of 10th IEEE Photovoltaic Specialists Conference 1973: pp. $40-49$.

5. Fossum, J.G., Nasby, R.D., Pao, S.C. Physics Underlying the Performance of Back-Surface-Field Solar Cells IEEE Transactions Electron Devices ED-27 1980: pp. 785-791. http://dx.doi.org/10.1109/T-ED.1980.19937

6. Fossum, J.G. Physical Operation of Back-Surface-Field Silicon Solar Cells IEEE Transactions Electron Devices ED-24 1977: pp. $322-325$.

http://dx.doi.org/10.1109/T-ED.1977.18735

7. Dunbar, P. M., Hauser, J. R. A Study of Efficiency in Low Resistivity Silicon Solar Cells Solid State Electronics 19 1976: pp. $95-102$.

8. Hauser, J. R., Dunbar, P. M. Performance Limitations of Silicon Solar Cells IEEE Transactions Electron Devices ED-24 1977: pp. 305-321.

http://dx.doi.org/10.1109/T-ED.1977.18734
9. Fossum, J.G. Computer-Aided Numerical Analysis of Solar Cells Solid State Electronics 19 1976: pp. 269-277.

10. Kopp, J., Knobloch, J., Wettling, W. The Influence of Oxide Thickness on The Passivation of High Efficiency Silicon Solar Cell. In: Proc. 11th European Photovoltaic Solar Energy Conference, Montreux, 1992: pp. 49-52.

11. Mandelkorn, W., Lamneck, J. H. Simplified Fabrication of Back Surface Electric Field Silicon Cells and Novel Characteristics of Such Cells Proceedings of 9th IEEE Photovoltaics Specialists Conference 1972: pp. 66-71.

12. Choe, K. S. Parametric Simulation of the Back-Surface Field Effect in The Silicon Solar Cell Solid State Sciences 29 2014: pp. $48-51$.

13. ATHENA User's Manual, SILVACO International. Santa Clara, 2012.

14. ATLAS User's Manual, Device Simulation Software, SILVACO International. Santa Clara, 2012.

15. Marques, F.C., Urdanivia, J., Chambouleyron, I. A Simple Technology to Improve Crystalline-Silicon Solar Cell Efficiency Solar Energy Materials and Solar Cells 52 1998: pp. $285-292$. http://dx.doi.org/10.1016/S0927-0248(97)00242-0

16. Münzer, K.A., Holdermann, K.T., Schlosser, R.E., Sterk, S. Thin Monocrystalline Silicon Solar Cells IEEE Transactions Electron Devices 46 1999: pp. 2055-2061. http://dx.doi.org/10.1109/16.791996

17. Bowden, S., Duerinckx, F., Szlufcik, J., Nijs, J. Rear Surface Passivation of Thin Multicrystalline Silicon Solar Cells OptoElectronics Review 8 (4) 2000: pp. 307-310.

18. Kaminski, A., Vandelle, B., Fave, A., Boyeaux, J.P., Le Quan, N., Monna, R., Sarti, D., Laugier, A. Aluminium BSF in Silicon Solar Cells Solar Energy Materials and Solar Cells 72 2002: pp. 373-379. http://dx.doi.org/10.1016/S0927-0248(01)00185-4

19. Metzger, W. How Lifetime Fluctuations, Grain-Boundary Recombination, and Junctions Affect Lifetime Measurements and Their Correlation to Silicon Solar Cell Performance Solar Energy Materials and Solar Cells 92 2008: pp. 1123-1135.

20. Ahrenkiel, R. K. Recombination Processes and Lifetime Measurements in Silicon Photovoltaics Solar Energy Materials and Solar Cells 76 2003: pp. 243-256. http://dx.doi.org/10.1016/S0927-0248(02)00277-5

21. Pla, J., Tamasi, M., Rizzoli, R., Losurdo, M., Centurioni, E., Summonte, C., Rubinelli, F. Optimization of ITO Layers for Applications in a-Si/c-Si Heterojunction Solar Cells Thin Solid Films 425 2003: pp. 185-192. http://dx.doi.org/10.1016/S0040-6090(02)01143-4

22. Janßen, L., Windgassen, H., Bätzner, D.L., Bitnar, B., Neuhaus, H. Silicon Nitride Passivated Bifacial Cz-Silicon Solar Cells Solar Energy Materials and Solar Cells 93 2009: pp. $1435-1439$. http://dx.doi.org/10.1016/j.solmat.2009.03.015

23. Cuevas, A., Russel, D. Co-Optimisation of The Emitter Region and The Metal Grid of Silicon Solar Cells Progress in Photovoltaics Research and Applications 8 2000: pp. 603-616.

24. Morales-Acevedo, A., Santana, G., Martel, A., Hernández, L. Effects of High Temperature Annealing of Aluminum at The Back of $\mathrm{n}^{+}-\mathrm{p}-\mathrm{p}^{+}$Silicon Solar Cells Upon Their Spectral and Electrical Characteristics Solid State Electronics 43 1999: pp. 2075-2079.

25. Lee, J., Lakshminarayan, N., Dhungel, S.K., Kim, K., Yi, J. Optimization of Fabrication Process of High-Efficiency and Low-Cost Crystalline Silicon Solar Cell for Industrial Applications Solar Energy Materials and Solar Cells 93 2009: pp. 256-261. 